\title{
UMA RABISCADORA: HELENA LIMA SANTOS, CRONISTA DO ALTO SERTÃO BAIANO
}

\section{A DOODLER: HELENA LIMA SANTOS, CHRONICLER OF BAHIA'S HIGH BACKWOODS}

Maria Lúcia Porto Nogueira ${ }^{1}$ Zoraide Portela Silva ${ }^{2}$

1 Professora Adjunta de História da Universidade do Estado da Bahia (UNEB).

2 Professora do Departamento de Ciências Humanas (DCH/VI) da Universidade do Estado da Bahia (UNEB). 
Resumo: No presente artigo, buscamos analisar as práticas discursivas de Helena Lima Santos, escritora baiana, em textos jornalísticos produzidos na década de 1990. Na perspectiva dos estudos feministas e literários, utilizamos as categorias "experiência" e "memória" para analisar a forma como a autora procurou defender a cultura sertaneja e a preservação das singularidades de um espaço-tempo social. Selecionamos doze crônicas sobre educação, ensino de qualidade, defesa do patrimônio histórico e cultural e críticas a conjunturas político-sociais para esmiuçar e problematizar as questões de gênero sub-repticiamente implícitas nas narrativas, sem desprezar os rastros de uma escrita autobiográfica.

Palavras-chaves: Helena Lima Santos, memória, estudos feministas, gênero, literatura. 
Abstract: In this paper, we aim to analyse the discursive practices of Helena Lima Santos, a writer from Bahia, in journalistic texts from the 1990s. As to feminist and literary studies, we used the categories "experience" and "memory" in order to analyse the manner in which the author intended to defend the backwoods culture and the preservation of the singularities of a social space-time. We assembled twelve chronicles on education, good teaching, historical heritage defence as well as criticism to social-political juncture for purposes of thoroughly investigating the author's gender questions, which are implicit in her narratives, without overlooking the trails of an autobiographical writing.

Keywords: Helena Lima Santos, memory, feminist studies, gender, literature. 


\section{Considerações iniciais}

Se para escrever, como disse Clarice Lispector (1968, p. 59), “o aprendizado é a própria vida se vivendo em nós e ao redor de nós", podemos dizer que Helena Lima Santos ${ }^{3}$ acumulou condições para a arte da escrita, estribada em longa trajetória de vida e de serviços prestados à sociedade caetiteense ${ }^{4}$. Assim, neste artigo, privilegiamos as práticas discursivas dessa mulher professora, escritora, esposa, mãe, avó e amiga, que soube problematizar as suas experiências a serviço da cultura sertaneja. Tomando como fontes as crônicas de sua autoria, publicadas entre

3 Nasceu e viveu no Estado da Bahia, em Livramento de Brumado (hoje Livramento de Nossa Senhora), no ano de 1904, formou-se em Salvador e veio a lecionar na Escola Normal de Caetité, em 1926, cidade que adotou aos 22 anos, quando iniciou sua atividade profissional, ali residindo até 1998, ano da sua morte. Escreveu e publicou na Revista de Educação da Escola Normal. Publicou o livro de memórias Caetité, pequenina e ilustre, em duas edições (1976 e 1997), citado por muitos que pesquisam sobre Caetité e região. Aposentou-se após 38 anos de trabalho na educação e, em 1985, iniciou sua contribuição escrita no Jornal Tribuna do Sertão, adotando a crônica como gênero literário. Ao longo de oito anos, Helena escreveu na coluna "Coisas do passado", que mudou o nome para "Crônica da Semana" em 1993. Após sua morte, a coluna do jornal passou a ter o seu nome.

4 Caetité é um município localizado no Sudoeste da Bahia, numa região historicamente conhecida como Alto Sertão, cuja sede dista aproximadamente $700 \mathrm{~km}$ da capital do estado. A cidade apresentou grande influência no campo educacional e na formação de professoras e professores, principalmente na virada do século XIX e primeira metade do século XX, que lhe valeram o título de Princesa do Sertão. 
1985 e 1998, no Jornal Tribuna do Sertão $o^{5}$, analisamos a forma como ela procurou defender e garantir uma memória, com vistas à preservação das singularidades de um espaço-tempo social.

$\mathrm{Na}$ perspectiva dos estudos feministas e literários, as duas categorias conceituais experiência e memória tornam-se importantes nesta análise que, embasada no pensamento de estudiosas como Scott (1990; 1999), Dias (1992; 2019), Brah (2006) e Rago (1998), busca considerar as suas imbricações com a subjetividade, a identidade e as amplas relações sociais da autora.

Tomando o seu lugar de fala, Helena Lima Santos (doravante Helena) expressou-se para justificar a sua faina pelo desejo de escrever:

No decorrer do tempo e o desaparecimento dos mais velhos, e sem que o percebesse muito bem, tornei-me este escriba sem outro fim senão o de não deixar acabar. É uma atividade para qual as circunstâncias da vida me empurraram. Ensinando gerações de sertanejos, vendo a cidade e a região se transformarem pelo efeito do trabalho dos professores que iam saindo da escola normal desde 1929, tendo contato com muita gente e ouvindo seus casos, interessando-me cada vez mais pelas famílias extintas e em extinção, publicando um livrinho onde pude deixar, ao menos um pouco do que ia sabendo, afinal, e para ajudar um pouco no começo da Tribuna do Sertão, tornei-me uma rabiscadora... (SANTOS, 1996a, p. 4)

$5 \quad$ O jornal fundado em 1985 (ainda em funcionamento) com sede em Brumado, na Bahia, é de propriedade de descendentes diretos da escritora. 
Desse modo, Helena justificou a sua atividade de escrita. 0 seu livro de memórias, publicado duas vezes - Caetité, pequenina e ilustre (1976 e 1997) - é fonte fecunda para pesquisas acadêmicas que versem sobre temas relacionados ao Alto Sertão da Bahia ${ }^{6}$. Para além desse texto, analisamos neste artigo a sua produção de rabiscadora, direcionada para as contribuições ao Jornal Tribuna do Sertão, quais sejam as crônicas ${ }^{7}$ feitas até os dias que avizinharam seu falecimento.

Deve-se a Davi Arrigucci a famosa consideração de que o cronista é um hábil artesão da experiência, pois ficcionaliza os acontecimentos retirados do cotidiano das cidades e os ressignifica. Ainda de modo mais ligado à memória, o crítico considera que "lembrar e escrever: trata-se de um relato em permanente relação com o tempo, de onde tira, como memória

6 Denominação histórica da região administrativa classificada hoje como Sertão Produtivo, localizada a Sudoeste da Bahia. Segundo Estrela, a utilização do termo "designa uma vasta área do interior do Brasil, situada na atualidade nos limites de dois Estados diferentes, revela claramente a existência de uma região imaginária na geografia do extremo sudoeste da Bahia [...] a qual tem sua origem na formação territorial do Brasil Colônia" (ESTRELA, 2003, p. 37).

7 A crônica, enquanto "gênero literário", começou a tomar forma no Brasil ainda no século XIX como uma maneira de transformar a aridez da literatura canônica (que com seus rebuscamentos serviam, às vezes, como filtros da realidade e da verdade) em algo mais palpável aos leitores. A crônica, segundo Antônio Candido (1992, p. 88-99), "está a estabelecer ou restabelecer a dimensão das coisas e das pessoas". Isso acontece, segundo o estudioso, porque ela é filha do jornal e se torna jornalística quando este passa a ser cotidiano, isto é, a ter uma tiragem relativamente grande e um teor acessível. 
escrita, sua matéria principal, o que fica do vivido" (ARRIGUCCI, 1987, p. 51). Podemos considerar que Helena Lima Santos se apresenta, então, como uma artesã da experiência feminina, caetiteense, dadas as suas condições de produção e de escrita.

\section{As Crônicas de Helena Lima Santos}

Em suas numerosas crônicas, bem tecidas e insistentes em defesa da educação, Helena Lima assumiu um lugar de formadora de opiniões, disseminando a ideia do valor de um ensino de qualidade e de políticas públicas voltadas para a área, por acreditar que aí se assentavam as bases do desenvolvimento local e regional. Tais registros permitem-nos vislumbrar quadros multifacetados acerca da educação, da formação docente e da posição de professoras e professores no cenário das relações de poder - com suas conjunturas políticas - que permearam os múltiplos espaços e temporalidades das suas vivências.

A produção em pauta pode ser analisada sob diferentes enfoques e dividida por temas, dentre os quais três nos interessam aqui: a) narrativas sobre educação, ensino de qualidade e Escola Normal de Caetité espaço de suas vivências como professora de Geografia Geral por mais de 30 anos; b) narrativas em defesa do patrimônio histórico e cultural do município e da região; c) posições críticas a conjunturas político-sociais. Interessa-nos, ainda, esmiuçar os rastros que 
dão a ver questões de gênero implícitas nos recônditos de suas práticas discursivas.

As práticas discursivas nos permitem observar os posicionamentos dos enunciadores, como eles acumulam suas experiências e como vão se constituindo, enquanto sujeitos, através da experiência. Na esteira do pensamento de Scott (1999, p. 27), entendemos experiência como "aquilo que buscamos explicar, aquilo sobre o qual se produz conhecimento". Nesse sentido, é possível percebermos que escrever após os 80 anos permitiu à cronista caetiteense fazer reflexões e desnudar subjetividades ausentes em escritos anteriores.

\section{Defensora da educação e cidadã inquieta}

$\mathrm{Na}$ perspectiva de reconhecimento do trabalho das/dos professoras/es, Helena afirmou, referindo-se às/aos egressas/os da Escola Normal, desde 1929, sua primeira turma de formandos, que ensinar às gerações de sertanejos foi a mola propulsora da transformação da cidade e da região. Além de Caetité, local em que residiu a maior parte da sua vida, suas incursões espaciais estiveram circunscritas à sua região de origem, a Chapada Diamantina, e à capital baiana, onde se diplomou professora em 1925. Não obstante a inegável importância de sua proximidade com a realidade local, demonstrou em seus escritos ter uma visão ampliada da realidade educacional do 
Brasil, trazendo reflexões sobre o analfabetismo e a tradição herdada do período do Império. Escreveu que o problema, principalmente na Bahia, não é bem a falta de escolas ou de professores, mas de direção e organização dos gestores, uma vez que há desvio das verbas que deveriam chegar às salas de aula. Aponta a evasão escolar no contexto da década de 1990 e critica o acesso limitado de estudantes às universidades federais, enquanto se expande o ensino superior de iniciativa privada, de custos elevados e nem sempre de boa qualidade (SANTOS, 1992).

A autora também nos surpreende, por vezes, com uma visão de cidadã pessimista acerca do conceito de Brasil na relação com o mundo, quando afirma que, como país de Terceiro Mundo, acumula as mazelas da "ignorância nativa herdada de índios e escravos" (SANTOS, 1992, p. 4) e encontra-se muito longe das condições ideais para erradicação do analfabetismo ${ }^{8}$. Critica o fato de existirem pessoas que imitam usos e costumes do Primeiro Mundo, embora reconheça as

8 É importante lembrar que essa sua posição com relação à herança cultural de índios e negros deve ser historicizada, isto é, deve ser colocada em seu contexto histórico. Hoje sabemos que a herança deixada pelos negros e índios dos começos de nossa formação social transcende e muito o que foi por bastante tempo considerado pelos intelectuais da cultura nacional. Racista era toda a elite da época em que estudou nossa cronista, embora isso não fosse confessado. Para se ter uma ideia, até a Constituição de 1937, a chamada "Polaca" e "democraticamente" elaborada, pregava a eugenia. 0 espírito da época era bem menos liberal e o racismo estrutural pairava no ar, à direita e à esquerda. É necessário, portanto, uma visão desarmada para as concepções de nossa autora. 
"exceções de brilhantes cientistas, literatos, poetas, artistas" (SANTOS, 1992, p. 4) e acredite nas potencialidades de um povo inteligente que até já inventou “o famoso 'jeitinho brasileiro', um quebra-galho em ocasiões difíceis" (SANTOS, 1992, p. 4).

Desfrutando de um conceito de educadora respeitada por sucessivas turmas de estudantes, Helena investia numa posição de disseminadora de opiniões, trazendo a lume questões políticas e sociais emblemáticas na administração pública e decisões ligadas à vida dos cidadãos e cidadãs, quer seja em nível local ou nacional. Ora, se os governantes têm a missão de dirigir o futuro de sua terra, eles não podem desconhecer a memória do lugar, e, por isso, não podem ser “ignorantes do seu passado" (SANTOS, 1992, p. 4). Todavia, conforme já se posicionava a escritora, muitos o são na medida em que apagam a história, destruindo prédios públicos e particulares, verdadeiros patrimônios culturais. A esse respeito, ela assim escreve:

Quando é o homem comum, do povo, tudo bem, vive-se como pode, mas quando se trata de governantes, o caso muda de figura, pois sua missão, além da honestidade, é dirigir o futuro histórico de sua terra. E como ele pode fazer isso se é ignorante do seu passado? Além de não promover a conservação de prédios públicos e particulares que são história, legislam em causa própria com os escandalosos aumentos que vão encarecendo a vida de todos em cadeia: ele - o político - pode pagar muito mais por qualquer produto, e ainda acha barato - e este produto, imediatamente, 
passará a ter aquele valor, pois os feirantes não são tolos. (SANTOS, 1992, p. 4)

Nesse caso, Helena ergue a voz contra uma situação de aumento dos preços no comércio, ao que parece dos gêneros de primeira necessidade, quando pessoas detentoras de melhor poder aquisitivo assumem atitudes que reverberam em aumento em cascata do valor dos produtos e alta do custo de vida, trazendo insatisfação, principalmente, para os menos favorecidos.

Nesse afã, desnuda outros vícios dos que se dedicam à vida política. Com olhar crítico, e como cronista observadora da conjuntura dos anos 1990, registra fatos recorrentes entre os governantes e representantes do povo que modificam as leis para enquadrar seus interesses, vaidades e ambições pelo poder. Lembra a situação de mais de 100 distritos que, mesmo estando em desacordo com as exigências constitucionais para o processo de emancipação, estão na fila para se constituírem como unidades administrativas independentes. De acordo com Helena, os futuros chefes políticos só estão interessados no número de votos que terão em cada um dos distritos beneficiados (SANTOS, 1992, p. 4).

Em outra publicação, torna-se mais contundente a sua crítica à forma com que o governo é conduzido, afirmando que "os representantes estaduais foram atacados de uma orgia emancipalista” (SANTOS, 
1992, p. 4) ao desconsiderarem a lei que regulamenta a questão. Não se mostram preocupados em garantir minimamente à população os serviços básicos como água encanada, estação de tratamento de água, luz elétrica, postos de saúde, etc. Sobre esgotamento sanitário, "praticamente inexistente, com raríssimas exceções", admitiu: "como é obra que fica debaixo do chão, não aparece, não dá ibope, não é feita por ineficiência administrativa ou talvez por ignorância; os prefeitos não cuidam desses serviços em suas cidades" (SANTOS, 1992, p. 4). Logo, obra que fica debaixo do chão, não é prioridade e assim vai se configurando mesmo a ineficiência e a ignorância administrativas, acusa a cronista.

Ao observar a administração dos sucessivos gestores municipais de Caetité, Helena escreveu uma série de crônicas protestando contra reveses e golpes na desconstrução da memória do lugar, se opondo a demolições feitas sem nenhum critério ou justificativa. 0 Teatro Centenário, construção do início do século XX, inaugurado em 1922, foi inexplicavelmente demolido em 1970. Apesar de o teatro estar desativado, a população tinha esperança de que houvesse a sua recuperação, no entanto o mais inexplicável foi que “Pasmem! a Câmara de Vereadores doou - d-o-o-u!" o terreno para um banco particular construir sua sede (SANTOS, 1992, p. 4).

As publicações de 1998, produção intensa nos 3 últimos meses da sua existência, insistiram na pre- 
servação da memória local. Nelas, Helena analisou as contradições da administração municipal e os embates dos habitantes da Praça do Alegre sobre os planos urbanísticos (ou ausência deles) na reconstrução da praça. Registrou a inauguração da Casa Anísio Teixeira e voltou a registrar histórias da Escola Normal, intitulando a sua última crônica de "Ainda sobre o Salão Nobre da Escola Normal - A Tela do Cristo".

\section{Helena e a escrita de si}

Ao adotar a estratégia da comparação de épocas passadas com o período contemporâneo, Helena deixa transparecer a sua subjetividade na relação com o tempo. A partir dos estudos de Nogueira (2016), é possível afirmar que o tempo da escrita em idade avançada permitiu-lhe reflexões que resvalaram para narrativas autobiográficas, ausentes nos trabalhos anteriores em que priorizava focalizar histórias de pessoas e famílias ligadas à educação ou ao desenvolvimento do município e da região, além de traçar quadros dos costumes em diferentes temporalidades.

Se em outros escritos quase nada se pode apurar de histórias pessoais, constatamos nos textos jornalísticos uma recorrência a fatos relacionados à sua própria vida. Escrevendo sobre si mesma, sobre os/as outros/as e acerca do que se passava no dia a dia e no seu entorno, Helena foi revelando seu perfil, seus modos de ser, seus saberes e singularidades 
que emergem na sua narrativa, sendo-lhe facultado o lugar de intérprete da sua própria história (SOUZA, 2008).

Mas o que levou Helena a assumir uma escrita mais voltada para si mesma? Essa pergunta nos remete a uma reflexão de Clarice Lispector (1984) sobre ser cronista, quando da sua colaboração no Jornal do Brasil, entre 1967 e 1973: à época, preocupada com o novo estilo de escrita, constatou que, à medida que ia escrevendo para o jornal, ia se "tornando pessoal demais", talvez porque a disseminação dos textos por um veículo mais acessível e mais aberto do que seria através de um livro tenha provocado a transformação na forma de escrever (LISPECTOR, 1984). No caso de Helena, o mesmo motivo pode ter influenciado a sua inclinação para uma escrita mais confessional, tendo a favor a sua fase da velhice adiantada, quando as reminiscências vêm à tona com mais facilidade. Um exemplo nos é dado em outubro de 1996, quando escreveu Palavras aos colegas - outubro de 1996, em homenagem aos colegas na passagem do dia dos professores:

Sempre desejei ser professora e não me decepcionei; a minha carreira foi uma estrada larga e ensolarada, sem tropeços nem pedregulho. Como se sente ao aposentar-se? Indagavam os amigos e a minha resposta sempre foi: ... como uma pessoa que se retira de uma festa já de madrugada... porque era hora! (SANTOS, 1997c, p. 4) 
Para a matéria-prima da sua memória, Helena justificou que começou a tomar conhecimento das histórias do povo do lugar em sua temporada de estudos no Colégio Imaculada Conceição, em Caetité (19191920), ainda adolescente, em contato com colegas da cidade, que foram acrescidas de muitas outras angariadas já como professora da Escola Normal (1926) e através de muitas pesquisas acumuladas ao longo do tempo. Nesse sentido, estudiosas e estudiosos da memória (como Perrot, 1989; Thompson, 1998 e Federici, 2019) asseveram que as memórias femininas, com as especificidades dos olhares atentos de quem escreve, buscam manter vivas as vozes do passado e as histórias das comunidades às quais pertenceram e, ao fazerem isso, traduzem pormenores e promovem a criação de uma identidade coletiva e um profundo senso de união e pertencimento. Daí podermos dizer que Helena se tornou uma tecelã da memória registrando fatos, acontecimentos, histórias dos sertões baianos e da sociedade caetiteense, que, transmitidos às gerações futuras, servirão para evitar a amnésia social.

Lembrando a prática dos castigos físicos e a "sabatina puxada à palmatória” (SANTOS, 1992, p. 4), a cronista registrou sua indignação por ter recebido o corretivo quando em seus estudos iniciais. Daí ter afirmado que, na segunda década do século XX, "A escola não era risonha e franca...” (SANTOS, 1992, p. 4), 
porém, voltando-se para o momento da escrita, admitiu:

Em nome da humanidade foram abolidos os castigos físicos, que faziam parte do ensino, todos, e tal ponto que o exagero tornou-se contraproducente. Hoje, até os franceses reclamam da falta de "um reforço negativo", isto é, algo como boas reguadas nos recalcitrantes, de tal modo a juventude tomou o pião na unha e malbarata a liberdade que gozam, esgotando o tempo e a paciência dos professores. (SANTOS, 1992, p. 4)

Nessa escrita de 1992, Helena admite ser necessário evitar os excessos praticados por discentes que acabam por atrapalhar os bons resultados do ensino. Em uma crônica escrita três anos depois, tomou a defesa do ensino ministrado na escola em que lecionava, a propósito do lançamento do Programa Nacional de Educação, quando o então Presidente, Fernando Henrique Cardoso, apontou entre os objetivos do programa uma melhoria da qualidade de ensino. A escritora não admitia a falta de reconhecimento do trabalho de professoras diplomadas pela Escola Normal de Caetité, abnegadas em prol do ensino na zona rural. Nesses espaços, analisou a situação do ensino em dois momentos. Antes das muitas facilidades de transporte, as professoras, na maioria dos casos, assumiam classes nas zonas rurais, onde instalavam residência por um tempo maior e, como educadoras no sentido mais amplo da palavra, exerciam o magistério com dedicação e grande influência na vida de toda a comunidade, 
além de ensinarem a ler e escrever. 0 mesmo já não acontecia na década de 1990, quando as idas e vindas semanais não deixavam espaço para que as docentes pudessem educar e modificar o ambiente 9 .

Em uma comemoração de reencontro de colegas professoras/es, em 1996, seu discurso versou sobre o reconhecimento devido às educadoras:

Somos o alicerce de uma sociedade que se eleva da ignorância, procurando a grandeza de uma civilização. (...) Somos as pedras do alicerce da educação de um povo, e como se sabe, os alicerces não aparecem, mas sem ele nenhuma construção se mantém firme. (...) Somos os ajudantes de uma grande obra, e também como se sabe, os ajudantes ganham ínfimos salários, sempre menores que os Mestres de Obra e Construtores. (SANTOS, 1997c, p. 4)

Ainda que a sua descrição seja eivada de um romantismo persistente quanto ao magistério, Helena enxerga as injustiças no tocante aos salários mal pagos, sempre defasados e incompatíveis com as duras jornadas da docência. Visto por muitos como um trabalho menor e rotineiro, ainda assim, afirma, é uma "voz se erguendo no silêncio" (SANTOS, 1997c, p. 4), pois todo o empenho dos professores da Escola Normal de Cae-

9 A escolha da cidade de Santa Maria da Vitória, no oeste baiano, em 09/02/1995, para lançamento do programa, bem como o forte esquema de proteção ao presidente, também passaram pelo crivo da narradora, na crônica "Por um ensino de qualidade" no Jornal Tribuna do Sertão (17/02/1995). 
tité "caiu em terreno fértil, multiplicou e mudou a face do sertão" (SANTOS, 1997c, p.4).

Nessa escola, as mulheres eram a maioria da turma concluinte em 1947, em que constavam apenas 4 homens. 0 encontro promovido para comemorar os 50 anos de formatura motivou a análise de Helena sobre a mudança de interesse dos homens em relação ao magistério. Eles cursavam o curso normal como porta de entrada para outras profissões mais rentáveis. Logo, não tinham interesse em tornarem-se educadores, o que contrastava com a posição de prestígio que ocupavam na virada do século XIX. Assim, Helena percebeu que o magistério como profissão teria as mulheres em suas fileiras, rumo a uma feminização da profissão, intuindo que a educação poderia representar a direção certa na conquista da emancipação feminina.

Como assinalaram outras estudiosas dessa cau$\mathrm{sa}^{10}$, as pressões da sociedade com exigências às mulheres para corresponderem aos padrões de comportamento preestabelecidos foram empurrando-as para o magistério como opção de carreira mais viável, ainda que destruindo os sonhos das muitas que gostariam de ter outras formações profissionais. Nogueira (2016) traz notícias de moças sertanejas que queriam continuar estudos em outras cidades que oferecessem formação em profissões diferenciadas,

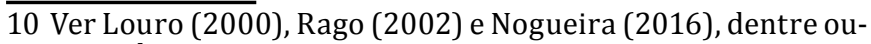
tros estudos. 
mas eram demovidas dos seus objetivos sob os pretextos de que não podiam ficar longe da família ou que tinham saúde frágil, quando o verdadeiro motivo esbarrava no fato de serem mulheres.

\section{Helena: ser mulher no sertão}

Em muitas das produções feitas para o jornal, Helena desnuda questões nodais da posição das mulheres na sociedade. Mesmo sem abordar explicitamente as ideias ou o movimento feminista, bem difundido no final do século XX, demonstrou sensibilidade acerca de questões femininas. Permitindo-se relembrar as histórias da sua infância e juventude, narrou práticas costumeiras ligadas ao patriarcalismo, machismo e sexismo, a exemplo da negação às mulheres do acesso à escola, privilégio apenas dos homens. 0 seu avô, professor concursado, teve 5 filhos homens e permitiu que todos estudassem, mas, às suas 5 filhas, foi negado esse mesmo direito e nenhuma sabia ler (SANTOS, 1992).

Quando estudante do curso normal, por volta dos anos 1920, vivenciou histórias que evidenciavam estigmas desfechados contra as estudantes. 0 professor de Ciências Físicas e Naturais, muito exigente, prometia reprovar as conversadeiras nos exames finais. Helena registrou a prática do professor de francês em requisitar a aluna em sua mesa para tomar a lição, bem no contexto de barulheira e desordem da classe. 
No primeiro caso, a autora nada mencionou, nem se perguntou pelos conversadores da sala de aula, porém, ao trazer essa imagem para o momento da escrita, manifesta perspicácia em perceber ali um sinal de misoginia. E no segundo caso, usando a palavra aluna, no singular, deixou-nos o alerta para uma situação de assédio (SANTOS, 1996a). Nesse sentido, vale dizer que os estigmas atravessaram o século e continuam existindo cotidianamente. Não por acaso, Sílvia Federici (2019) historiciza as perseguições feitas às mulheres em várias partes do mundo, ao longo de séculos, e lembra a existência de instrumento de tortura usado para puni-lass e obrigá-las a se manterem caladas, principalmente mulheres de estratos sociais inferiores, consideradas importunas, rabugentas ou subversivas, sempre suspeitas de bruxarias. Havia, portanto, a persistência de estigmas endereçados contra mulheres detentoras de saberes tradicionais ou lideranças comunitárias, consideradas como ameaça aos objetivos de dominação em sociedades conservadoras.

Os estudos feministas mostram que o acesso das mulheres às escolas foi um processo lento e cheio de dificuldades. Da falta de políticas de incentivo à abertura de escolas e a formação de professoras, sabemos ser o interior da Bahia bem castigado. Somente no final da década de 1920 é que os cursos de magistério começaram a aparecer, e Helena, de forma assertiva, reiterou várias vezes o quanto esses cursos trouxe- 
ram mudanças para o mundo feminino. Em seu livro Caetité, pequenina e ilustre (1997), explicou que ter acesso à escola ou cursar o magistério significava formar consciências mais esclarecidas, ter mais chances de conquistar autonomia, ainda que para o desempenho das funções de mães e donas de casa, pois elas saberiam educar melhor os seus filhos e filhas. Assim, não seria mais necessário levar moças para São Paulo em busca de casamentos vantajosos ou de empregos.

No contexto baiano, em meados do século XX, nas regiões sertanejas da Bahia, as estatísticas mostram que as limitações e os preconceitos produziam posições desvantajosas para as mulheres, tanto no acesso ao magistério quanto em outras profissões ${ }^{11}$.

No Alto Sertão Baiano, na década de 1940, a memorialista Guiomar Coutrim (2010), que estudou numa zona rural, caminhava 9 quilômetros todos os dias para chegar à escola, mas à sua irmã mais velha não foi dado o mesmo direito de estudar porque deveria cuidar da casa, ajudar a cuidar dos irmãos e irmãs e auxiliar a mãe nos afazeres domésticos. Fatos como esse eram corriqueiros em prejuízo da educação das mulheres, daí porque Helena tanto valorizou a sua profissão e a Escola Normal de Caetité.

Isso nos remete a uma história dos idos de 1935, contada pela cronista. Um pai de família, contrário à

11 Para mais informações, ver Passos (1997) e Nogueira (2016), dentre outras produções. Segundo Passos (1997), nos anos $1940 / 50$ do século XX, apenas $9 \%$ das mulheres possuíam curso superior. 
educação das filhas, argumentava que o destino delas era casar e ter filhos, pois não queria que "ficassem soltas, por conta própria dando despesas" (SANTOS, 1997b, p. 4). No entanto, a sua mulher usou uma estratégia:

Calada foi forjando seu plano de ação, amealhando seus tostões para um futuro próximo. E um belo dia, aproveitando-se da ausência do marido na Câmara da cidade onde era Vereador, pegou dois dos filhos, uma menina e um menino menor, deixou a filha mais velha para tomar conta da casa, dos outros irmãos e do pai e veio para Caetité em companhia de um irmão, deixando um recado de que estando adoentada, ia a Brumado consultar-se com o Dr. Mário Meira. (SANTOS, 1997b, p. 4)

A personagem da história, com ajuda do irmão, comprou uma casa em Caetité, com seu próprio dinheiro, e deixou tudo bem organizado para que pudessem estudar. "Diante do clamor que a 'fuga' levantou naquele meio acanhado, onde as mulheres não tinham vez, ele [o marido] passou a declarar: 'ela foi com a minha aprovação!'” Todos os filhos e filhas concluíram a formação para professores/as. Uma delas, Adelaide, "a mais aventureira", foi exercer a profissão na capital baiana e, segundo Helena, "moça e forte não quis casar-se e dizia 'sou muito independente'" (SANTOS, 1997b, p. 4).

Então, por transformações como essa, o casamento, segundo descreveu na crônica "Nem tudo são flo- 
res" (SANTOS, 1993, p. 4), já havia deixado de ser o único destino das moças. Apesar de o título sugerir um estado de tristeza, admitiu que, na sociedade de meados do século passado, já havia espaço para moças solteiras viverem com autonomia a partir de conquistas de empregos que lhes permitiam atuar como professoras, bancárias, comerciantes ou outras profissões. Com essa independência, também poderiam escolher melhor os maridos ou até prescindir deles. Nesse ínterim, a escritora relata um episódio curioso para expressar a vivacidade da resposta de uma menina de oito anos, quando elogiada pela avó: "bonita assim e arrumada, vai achar logo, um noivo", ao que a menina respondeu: "pra casar, vó, não precisa ser bonita e estar bem arrumada; pra casar, é preciso esperteza!" (SANTOS, 1993, p. 4). Nesse sentido, sob o ponto de vista da narradora, por falta de "esperteza" é que muitas moças das cidades interioranas deixam de ser "excelentes mães de família".

Helena utilizou-se algumas vezes de episódios hilários como esse para elucidar situações corriqueiras da sua região e do Brasil, ao mesmo tempo em que mostrava seu ponto de vista e imprimia leveza ao seu estilo de escrita. Talvez por querer trazer à tona situações contraditórias, vividas por mulheres que ousavam resistir às normas sociais impostas, ora defendia a autonomia feminina, mesmo sem os laços matrimoniais, ora apontava o sucesso daquelas que optavam por viver em consonância com tais normas, viven- 
ciando o mundo da casa e o espaço privado como lugar da mulher.

Entretanto, prevalece em sua escrita, a crença reiterada no potencial feminino para ascensão social. Cita o exemplo de uma professora aposentada, cuja solteirice foi bem vivida, porque podia dispor do seu tempo e dinheiro como bem lhe aprouvesse, já que não tinha "imediatas obrigações familiares no dia a dia” (SANTOS, 1996c, p. 4).

Além de ter se destacado como docente e vereadora, revelou-se como organizadora do Clube da Amizade, um grupo social que reunia as muitas professoras aposentadas da cidade, com vistas a promover uma boa convivência, lazer e novas redes de sociabilidade. Afirmou, ainda, que o clube até admitia sócios masculinos, mas que esses nunca estavam disponíveis para as tarefas de direção (SANTOS, 1996c).

A questão da beleza feminina levantada acima evidencia outro ponto importante da escrita da cronista, quando se apropria do estigma beleza-feiura, tão presente e preocupante na constituição de subjetividades femininas. Ainda se reportando aos anos de sua formação no magistério, descreve uma professora: “D. Julia só tinha um defeito, era feia! Mas, era alegre e comunicativa e chegávamos a esquecer seus poucos traços atrativos fisionômicos" (SANTOS, 1996a, p. 4). No entanto, não podemos desconsiderar que o atributo da beleza foi amplamente associado ao modelo de mulher idealizado e imposto pelos padrões so- 
ciais. Publicada em maio de 1996, a crônica refere-se aos anos de formação da narradora no Educandário Sagrado Coração de Jesus, na capital baiana, contexto das vivências de uma jovem na segunda década do século passado, quando, conforme palavras de Sant'Anna, a penteadeira ainda era utensílio indispensável, "lugar ideal para o embelezamento e a prova da distinção social de cada mulher" (SANT'ANNA, 2003, p. 4).

'A eterna vaidade feminina' foi o termo pelo qual Helena se expressou, referindo-se à alegria feminina em ganhar presentes. Os vestidos, então, são o maior interesse, cultivado desde a infância por pais, avós, tias e padrinhos. Desde pequena, qualquer menina observa e inveja os vestidos das suas amigas, e cresce acostumada com isso, tornando-se "vaidosa de seus encantos, porque todas as mulheres têm uma primavera dourada, na juventude" (SANTOS, 1997a, p.4). Helena aborda esse assunto a propósito da sua imensa satisfação, aos 92 anos, em receber um vestido de presente de um ex-aluno, relembrando o que seu marido dizia em tom divertido: "o diabo as pinta", e, ainda, o adágio popular: "moças e chitas, não há feias nem bonitas". E arremata: "é um prazer que a vida me proporciona neste final de século e de vida!" (SANTOS, 1997a, p.4).

As reverberações da sensibilidade de Helena e de seus ângulos de observação condicionam o registro da posição das mulheres nos espaços sociais, apre- 
sentando-as em diferentes labores e assunção de atividades, como organizadoras de tarefas ou quaisquer outras coisas que pudessem garantir a realização de projetos de vida ou até mesmo a subsistência. Dessa maneira, buscou registrar histórias de resistência e sucesso rumo a uma autonomia financeira. Com essa intenção, trouxe a história de duas irmãs, uma solteira e outra viúva, já bem estabelecidas profissionalmente, empenhadas em suas estratégias para sobreviver: a primeira dava cursos de bordados para jovens e produzia peças de tecidos para enxovais de casa, enquanto que a segunda corria os sítios no entorno, em viagens para a venda das peças confeccionadas (SANTOS, 1997e). Vale lembrar que, em outro registro já citado, a autora nos narra o caso da esposa determinada que amealhou recursos e foi poupando-os para aplicá-los na execução do plano de transferir-se com seus filhos para Caetité com vistas à educação dos mesmos. A estratégia surtiu efeitos e configurou-se como uma das ações que promoveram significativas transformações naquela região, as quais não passaram despercebidas por Helena Lima Santos.

\section{Considerações finais}

0 grande diferencial da escrita de Helena cronista é a sua coragem em falar sobre si e sobre sua trajetória, apresentando toda a coerência de uma vida que atravessou o longo século XX. A narradora soube an- 
gariar respeito e inspirar confiança entre as pessoas com quem conviveu, de modo que seus escritos promovem reflexões profícuas em favor de mudanças de comportamento e de mentalidades favoráveis à melhoria das relações sociais, à preservação do patrimônio cultural, bem como à difusão de valores educacionais compatíveis com a nova realidade do século XXI.

Os textos de Helena apresentam uma identidade consolidada. Ao tecer suas narrativas, foi mostrando sua subjetividade e, numa via de mão dupla, foi imprimindo valor e significado aos seus escritos autobiográficos. Nesse ínterim, é interessante perceber que isso se dá transversalmente a temas relevantes principalmente para a história da cultura local e para a história da educação do Alto Sertão da Bahia. Numa atitude de quem já teve tempo e perspicácia de analisar fatos vivenciados e com a sabedoria de uma anciã, Helena Lima Santos escreveu ao ser presenteada por um ex-aluno: "Sempre estou a me lembrar dos versos: 'Do que houveres no pomar plantado, apanhe os frutos, recolha as flores'” (SANTOS, 1997d, p. 4). Devemos, portanto, considerar que, na "aventura de contar-se" (RAGO, 2013), Helena trouxe contribuições valiosas para a construção de um mundo mais humanizado. 


\section{Referências}

ARRIGUCCI JR, Davi. Enigma e comentário. São Paulo: Companhia das Letras, 1987.

BRAH, Avtar. Diferença, diversidade, diferenciação. Cadernos Pagu, Campinas, n. 26, p. 329-376, jun. 2006.

CANDIDO, Antônio. A vida ao rés-do-chão. In: Para gostar de ler: crônicas. São Paulo: Ática, 1992, v. 5 p. 88-99.

COUTRIM, Guiomar Ferreira. Determinada a ser feliz. Guanambi: Gráfica Bahia, 2010.

DIAS, Maria Odila Leite da Silva. Teoria e Método dos estudos feministas: perspectiva histórica e hermenêutica do cotidiano. In: COSTA, Albertina de Oliveira; BRUSCHINI, Cristina (Orgs). Uma Questão de Gênero. São Paulo: Fundação Carlos Chagas, 1992.

DIAS, Maria Odila Leite da Silva. Novas subjetividades na pesquisa histórica feminista: uma hermenêutica das diferenças. In: HOLLANDA, Heloísa Buarque de (Org). Pensamento feminista brasileiro: formação e contexto. Rio de Janeiro: Bazar do Tempo, 2019.

ESTRELA, Ely Souza. Os sampauleiros: cotidiano e representações. São Paulo: Humanitas, FFLCH/USP; FAPESP; Edusc, 2003.

FEDERICI, Sílvia. Mulheres e caça às bruxas: da idade média aos dias atuais. 1.ed. São Paulo: Boitempo, 2019. Tradução Heci Regina Candiani.

LISPECTOR, Clarice. Ser cronista. In: LISPECTOR, Clarice. A descoberta do mundo. Rio de Janeiro: Nova Fronteira, 1984. p. 67-68.

LOURO, Guacira Lopes. Gênero, sexualidade e Educação: uma perspectiva pós-estruturalista. Petrópolis: Vozes, 2014.

NOGUEIRA, Maria Lúcia Porto Silva. Mulheres baianas nas artes da escrita: tessituras de experiências, memórias e outras histórias (1926 -1960). 300f. 2016. Tese (Douto- 
rado). Faculdade de Filosofia Letras e Ciências Humanas da Universidade de São Paulo. São Paulo, 2016.

PERROT, Michele. Práticas da memória feminina. Revista Brasileira de História, São Paulo, v. 9, n. 18, p. 9-18, 1989. RAGO, Margareth. A aventura de contar-se: feminismos, escrita de si e invenções da subjetividade. São Paulo: Editora Unicamp, 2013.

RAGO, Margareth. Epistemologia feminista, gênero e história. In: PEDRO, Joana Maria; GROSSI, Miriam Pilar. Masculino, feminino, plural: gênero na interdisciplinaridade. Florianópolis: Ed. Mulheres, 1998, p. 21- 41.

RAGO, Margareth. Feminizar é preciso. Por uma cultura filógina. Revista Labrys - Estudos feministas, n. 1-2, p. 5866, jun/dez, 2002.

SANT'ANNA, Denise Bernuzzi de. A insustentável visibilidade do corpo. Revista Labrys, Estudos Feministas, n. 4, ago./dez. 2003.

SANTOS, Helena Lima. Caetité, pequenina e ilustre. Brumado: Jornal Tribuna do Sertão, 1997.

SANTOS, Helena Lima. Crônica: 0 Brasil e o analfabetismo. Jornal Tribuna do Sertão, Brumado, p. 4, 4 set. 1992.

SANTOS, Helena Lima. Crônica: Palavras aos colegas - outubro de 1996. Jornal Tribuna do Sertão, Brumado, p. 4, 7 mar. 1997c.

SANTOS, Helena Lima. Crônica: Continuand o...O curso normal. Jornal Tribuna do Sertão, Brumado, p. 4, 24 mai. 1996 .

SANTOS, Helena Lima. Crônica: Uma bonita história. Jornal Tribuna do Sertão, Brumado, p. 4, 28 fev. 1997b.

SANTOS, Helena Lima. Crônica: Nem tudo são flores. Jornal Tribuna do Sertão, Brumado, p. 4, 17 set. 1993.

SANTOS, Helena Lima. Crônica: Lacinho Vermelho. Jornal Tribuna do Sertão, Brumado, p. 4, 6 set. 1996c.

SANTOS, Helena Lima. Crônica: A eterna vaidade feminina. Jornal Tribuna do Sertão, Brumado, p. 4, 17 jan. 1997a. 
SANTOS, Helena Lima. Crônica: Flora e Gulorinha - Reminiscências. Jornal Tribuna do Sertão, Brumado, p. 4, 17 out. 1997e.

SANTOS, Helena Lima. Crônica: 0 lançamento da $2^{a}$ edição do meu livro Caetité, pequenina e ilustre. Jornal Tribuna do Sertão, Brumado, p. 4, 30 jun. 1997d.

SCOTT, Joan W. El gênero: uma categoria útil para el análisis histórico. In: AMELANG, James S.; NASH, Mary (Orgs). História y Género: Las mujeres en la Europa Moderna y Contemporánea. Valéncia: Edicions Alfons el Magnanium IUEL, 1990.

SCOTT, Joan W. Experiência. In: SILVA, Alcione Leite da; LAGO, Maria Coelho de Souza; RAMOS, Tânia Regina Oliveira (Orgs). Falas de Gênero. Florianópolis: Editora das Mulheres, 1999.

SOUZA, Elizeu Clementino de. (Auto)biografia, identidade e alteridade: modos de narração escritas de si e práticas de formação na pós-graduação. Revista Fórum Identidades, ano 2, v. 4, n. 4, p. 37-50, jul-dez. 2008.

THOMPSON, Paul. A voz do passado: história oral. 2 ed. São Paulo: Paz e Terra, 1998. Tradução Lólio Lourenço de Oliveira. 